NBER WORKING PAPER SERIES

\title{
ESTIMATING THE RELATIONSHIP BETWEEN ALCOHOL POLICIES AND CRIMINAL VIOLENCE AND VICTIMIZATION
}

\author{
Sara Markowitz \\ Erik Nesson \\ Eileen Poe-Yamagata \\ Curtis Florence \\ Partha Deb \\ Tracy Andrews \\ Sarah Beth L. Barnett \\ Working Paper 17918 \\ http://www.nber.org/papers/w17918
}

\author{
NATIONAL BUREAU OF ECONOMIC RESEARCH \\ 1050 Massachusetts Avenue \\ Cambridge, MA 02138 \\ March 2012
}

Funding for this study was provided by a contract from the Centers for Disease Control to IMPAQ International, LLC. We would like to thank Phil Cook for excellent help and suggestions. The findings and conclusions in this report are those of the authors and do not necessarily represent the official position of the Centers for Disease Control and Prevention or the National Bureau of Economic Research.

NBER working papers are circulated for discussion and comment purposes. They have not been peerreviewed or been subject to the review by the NBER Board of Directors that accompanies official NBER publications.

(C) 2012 by Sara Markowitz, Erik Nesson, Eileen Poe-Yamagata, Curtis Florence, Partha Deb, Tracy Andrews, and Sarah Beth L. Barnett . All rights reserved. Short sections of text, not to exceed two paragraphs, may be quoted without explicit permission provided that full credit, including $\odot$ notice, is given to the source. 
Estimating the Relationship between Alcohol Policies and Criminal Violence and Victimization Sara Markowitz, Erik Nesson, Eileen Poe-Yamagata, Curtis Florence, Partha Deb, Tracy Andrews, and Sarah Beth L. Barnett

NBER Working Paper No. 17918

March 2012

JEL No. I0,K0

\begin{abstract}
Violence is one of the leading social problems in the United States. The development of appropriate public policies to curtail violence is confounded by the relationship between alcohol and violence. In this paper, we estimate the propensity of alcohol control policies to reduce the perpetration and victimization of criminal violence. We measure violence with data on individual level victimizations from the U.S. National Crime Victimization Survey. We examine the effects of a number of different alcohol control policies in reducing violent crime. These policies include the retail price of beer, drunk driving laws and penalties, keg laws, and serving and selling laws. We find some evidence of a negative relationship between alcohol prices and the probability of alcohol or drug related assault victimizations. However, we find no strong evidence that other alcohol policies are effective in reducing violent crimes. These results provide policy makers with guidance on potential approaches for reducing violence through alcohol beverage control.
\end{abstract}

Sara Markowitz

Department of Economics

Emory University

1602 Fishburne Dr.

Atlanta, GA 30322

and NBER

sara.markowitz@emory.edu

Erik Nesson

Department of Economics

Emory University

1602 Fishburne Dr.

Atlanta, GA 30322

enesson@emory.edu

Eileen Poe-Yamagata

IMPAQ International, LLC

10420 Little Patuxent Parkway, Suite 300

Columbia, MD 21044

epyamagata@impaqint.com

Curtis Florence

National Center for Injury Prevention and Control

Centers for Disease Control

Atlanta, Georgia

gul4@cdc.gov
Partha Deb

Hunter College

Department of Economics

695 Park Avenue

Room 1524 West

New York, NY 10065

and NBER

partha.deb@hunter.cuny.edu

Tracy Andrews

IMPAQ International, LLC

10420 Little Patuxent Parkway

Suite 300

Columbia, MD 21044

troberts1975@gmail.com

Sarah Beth L. Barnett

National Center for Injury Prevention and Control

Centers for Disease Control

Atlanta, GA

Hun8@cdc.gov 


\section{Introduction}

Heavy alcohol consumption, crime, and violence are some of society’s most disruptive and costly social problems. The Healthy People 2020 agenda from the U.S. Centers for Disease Control and Prevention (CDC), lists the reduction of homicides and physical assaults as critical goals, along with reductions in alcohol consumption by among various populations (USDHHS 2010). The correlation between the consumption of alcoholic beverages and the incidence of violence has been well-documented in the U.S. and in various countries throughout the world (WHO 2004, Cnossen 2007). However, despite the close association of alcohol and violence, a question remains as to whether the relationship is causal. Many theories propose that the properties of alcohol cause people to become more violent or more vulnerable to victimization; however, it could also be true that people with violent tendencies self-medicate with alcohol or use alcohol as an excuse for their behavior, thereby lowering the potential penalties associated with violence. Moreover, the observed relationship between alcohol and violence could be spurious, and the two outcomes could be related only via a third factor, such as personality or environment (see Markowitz, 2005, for a complete discussion of these theories).

In this paper, we directly estimate the propensity of alcohol control policies to reduce perpetration and victimization rates of criminal violence. Using the reduced form policy analysis method of Cook and Tauchen (1982), we exploit the well-established relationship between alcohol consumption and the exogenous determinants of alcohol demand, such as prices and government alcohol control policies. By examining the effects of alcohol policies in reducing measures of violence, we can provide policy makers evidence on potential ways to reduce violence through alcoholic beverage control policies. The reduced form is also advantageous in 
that it avoids the endogeneity problem inherent in estimating the direct relationship between alcohol consumption and violence.

The reduced form method has been used extensively by researchers in the past to examine the direct impact of alcohol taxes and other control policies on various types of violence, including assault, rape, robbery, intimate partner violence, child abuse, and suicide (Grossman and Markowitz 2001; Markowitz 2005; Markowitz et al. 2003; Markowitz and Grossman 1998, 2000; Markowitz 2000; Cook 2007; Matthews et al. 2006). However, for the U.S., the bulk of this previous literature was conducted using data from the 1980s and 1990s, with few examples using data from beyond 2000. Also, most of this literature examines only a few alcohol control policies, mainly excise taxes, with some attention paid to drunk driving laws and availability measures. This is despite a plethora of policies currently used by states to control alcohol. In the analyses below, we describe and use sixteen different alcohol control policies in conjunction with very recent data on violent victimization for the U.S. We find some evidence of a negative relationship between alcohol prices and the probability of alcohol or drug related assault victimizations. However, we find no strong evidence that other alcohol policies are effective in reducing violent crime victimization for people of any age group.

\section{Background}

Early studies on the relationship between alcohol taxes and violent crimes among adults in the U.S. were written by Chaloupka and Saffer (1992) and Cook and Moore (1993). Using data from the FBI’s Uniform Crime Reports, both sets of authors look at rates of murder, rape, assault, and robbery during the 1970s and 1980s. Each estimates a reduced form model where the crime rate is a function of the state excise tax on beer and state-specific characteristics. Cook and Moore show that increasing the tax on beer reduces the rates of rape and robbery but has no 
effect on physical assault or homicide. Chaloupka and Saffer find similar results; higher beer taxes lower the rates of rape, robbery, and homicide, but not physical assault. Desimone (2001) conducts a similar analysis and finds a negative relationship between the state beer tax and assaults, rapes, and some types of property crimes. However, all of these studies only analyze crimes that have been reported to the police and are therefore limited in their generalizability. Using recent data from the NCVS, we calculate that less than half of violent crimes are reported to the police.

Other studies improve on this literature by using individual level data on victims. Markowitz (2005) uses victimization data from the 1992, 1993 and 1994 National Crime Victimization Surveys. Results show that higher beer taxes lower the incidence of assault and alcohol- or drug-involved assault, but not rapes or robberies. Results also show that fewer outlets licensed to sell alcohol are associated with a lower incidence of rapes. Matthews et al. (2006) use violence related injuries entering hospital emergency departments in England and Wales as their measure of violence. They find that higher beer prices are associated with reductions in this injury rate.

There is some evidence that crime rates may rise with a higher density of outlets licensed to sell alcohol, although all the research to date on this question focuses on small geographic areas and cannot be generalized to broader areas. Scribner et al. (1995) and Gyimah-Brempong (2001) show that violent crime rates increase with higher alcohol outlet densities in Los Angeles County and Detroit, respectively. Scribner et al. (1999) show that a higher outlet density is associated with a higher homicide rate in New Orleans. Other studies have examined the effects of closing times or allowed days of sale on crimes, but these studies are often limited in geography or are results of extraordinary circumstances (see for example Olsson and Wikstrom 
1982, Chikritzhs and Stockwell 2002 and Biderman et al. 2010). We refer the reader to

Carpenter and Dobkin (2010) for an in-depth discussion of this literature. ${ }^{1}$

The previous literature provides insights into the relationship between alcohol control policies and measures of violent crime. However, most of this research is based on data that are ten to twenty years old, or more. In recent years, real alcohol prices in the U.S. have been falling as states and the federal government have chosen not to raise alcohol taxes (see Figure 1 and Figure 2).

In the U.S., recent alcohol regulation has taken different forms, specifically, in terms of restrictions to access and availability. ${ }^{2}$ As a result of changes in alcohol prices and regulations in recent years, it is important to reexamine the findings from previous studies. In this paper, we revisit the question of whether alcohol control polices can be used to influence criminal violence in the U.S. We use the most recent data available and analyze a comprehensive series of alcohol regulatory variables.

\section{Data}

The data used in this paper come from a variety of sources. We use individual-level data from the National Crime Victimization Survey (NCVS) to measure violent victimization, and we supplement this with area-level alcohol policy information. Descriptions of each data source are below.

The NCVS is a nationally representative survey of households focusing on individuals' experiences with criminal victimization. The survey includes a rotating panel of individuals and

\footnotetext{
${ }^{1}$ There is also a large literature evaluating the effects of increases in the minimum legal drinking age on various outcomes, including crime, but the current policy relevance of this literature is limited (e.g. Carpenter 2007).

${ }^{2}$ In a study using data from 1984-1995, Sloan et al. (2000) analyze a comprehensive set of alcohol control variables, such as open container laws, dram shop laws, and social host laws. They estimate demand for alcohol equations and a reduced form model of traffic fatalities and find some of these laws to be effective in altering binge drinking and fatalities. Sloan et al. do not consider violent outcomes.
} 
is administered every six months for a three-year period. Because of the panel design, a person can have from one to six interviews recorded in this data. The publicly available geocoded version of this data is limited to individuals living in the core counties of the 40 largest MSAs (based on population) and is publicly available for 1994-2004. The samples in each MSA are representative of the population in the core counties. We analyze samples of respondents ages 18 and up to measure violence among adults, and also ages 18 to 29 to capture violence among young adults at the greatest risk for violence and victimization.

The main dependent variable is an indicator variable of whether or not the individual had been a victim of assault in the past six months. In addition, the NCVS asks each respondent who was victimized, "was the offender drinking or on drugs or don't you know?" Using the response to this question, we created an additional dichotomous dependent variable indicating whether or not the individual reports being a victim of an alcohol or drug involved crime. A response of "I don’t know" was assigned a missing value for this question. One limitation to this variable is that we do not know whether or not the victim had been drinking at the time of the attack. Similar questions are asked about robbery victimizations, and we create two additional dependent variables for robbery. Victimization rates are fairly low in this data. In a six month period, a person has a 0.6 percent chance of being the victim of at least one assault and a 0.2 percent chance of being the victim of at least one alcohol or drug involved assault. Victimization rates are much higher among young adults with rates of 1.2 percent and 0.5 percent for the overall and alcohol or drug involved victimizations, respectively.

The advantages of the NCVS data are that it directly measures victimization, we can split the sample by age to examine the policy effects for the high-crime age groups (young adults), and that the panel nature of the data allows us to include individual-level fixed effects in the 
models. Individual fixed effects are important as they help control for unobserved time-invariant characteristics about the individual that may make them more prone to victimization or risky behaviors such as drinking.

Data on criminal offenses reported to the police are another potential source of violent crime data. However, offense data may suffer from a reporting bias that is unlikely to be present in the victimization survey. Offense data for the U.S. is not consistently reported by police precincts, and it is possible that offenses reported (or not reported) are systematically related to alcohol consumption and prices, which could bias the effects of the policies towards zero. Such a situation might occur if people in areas with low alcoholic beverage prices consume more alcohol, engage in violence, but do not report assaults to the police. Goldstein (1985) reports that many intoxicated victims do not report their victimizations because they do not wish to talk to the police while drunk. Also, these victims may be confused about the details of the crime and may believe that reporting the crime would be futile. Given all this, we believe the victimization data is the best available source for violent crime.

All models also include time varying observable characteristics of the respondents such as marital status, education, and household income. We include a series of dummy variables for the years in which the respondent was interviewed to help capture some of the national trends in violent crimes. To control for other geographic characteristics likely to be associated with crime, we include a one year lag of state prison incarceration rates, the state real income per capita, the state unemployment rate, the percentage of the state population ages $15-24$, the percentage of the state population that is black, the percentage of the state population ages 25 years and over that has obtained a bachelor's degree, and the percent of the state living in rural areas. State spending on police comes from the Bureau of Justice Statistics. Data on prison populations by state come 
from the Bureau of Justice Statistics’ National Corrections Reporting Program. Per capita income comes from the Department of Commerce, and unemployment comes from the U.S. Bureau of Labor Statistics. The other state demographics come from the U.S. Census Bureau.

The first alcohol control policy of interest is the price of alcohol, which can be manipulated through legislated excise tax changes. We do not use the alcohol taxes directly in this project because very few states changed their excise taxes during the 2000s. Our methodology requires sufficient variation in the taxes for proper identification of the true effects, and this variation is simply not present. Instead we rely on the retail price of beer from the quarterly ACCRA Cost of Living Index, which exhibits variation not only because of excise taxes, but also because of differences in production and transportation costs. Beer is chosen because it is the most popular beverage in terms of consumption of pure ethanol per capita. The ACCRA beer prices are measured on an MSA level, so we match the MSAs in ACCRA to the MSAs in the NCVS data. Note that not all MSAs are represented in ACCRA in each time period, which generates some missing values in the panel.

The ACCRA price data have some limitations. Young and Bielinska-Kwapisz (2003) discuss the potential measurement error contained in the price series, stemming in part from the data collection process and the focus on urban areas. Ruhm et al. (2011) also cite issues with the lack of representativeness of the beverage prices, which can be particularly erroneous when consumers substitute from higher to lower price alcoholic beverages. Ruhm et al. (2011) recommend using Uniform Product Code scanner data prices. In their paper, they find that the ACCRA prices are overstated compared to that of alcoholic beverages sold in grocery stores. In their analysis, however, they necessarily omit states where alcohol is not sold in grocery stores, which limits the number of states analyzed. At present, the ACCRA prices are the best option 
available to us. While the price level may be overstated, our estimation relies on changes in the prices, not the level per se, and Young and Bielinska-Kwapisz (2002) find the ACCRA prices track national trends very well.

One variable that represents the availability of alcohol is the number of outlets licensed to sell liquor per 1,000 state residents. Data on licensed outlets come from the Adams Liquor Handbook. We caution that outlets can be endogenous in a crime equation if there are unobserved neighborhood characteristics that determine both the level of crime and the availability of alcohol. However, the individual-level fixed effects will help mitigate this source of endogeneity.

We include a host of other alcohol control policies gathered from the Alcohol Policy Information System (APIS). These data are available online through the National Institute on Alcohol Abuse and Alcoholism (NIAAA). For the years that were not available online, IMPAQ researched state statutes and contacted state officials to provide a continuous time series for these data over time. We use sixteen policy variables within different policy areas, as shown and described in Table 1 below. These laws can be broadly grouped into the following: Laws pertaining to the purchase of kegs, drunk driving laws, laws pertaining to serving and selling alcohol, Sunday sales, open container laws, and miscellaneous laws pertaining to underage drinking.

The details of laws regulating the sale and availability of alcohol are complex and vary from state to state, and we refer the reader to the APIS for specific details, but some of the main ones are summarized here for clarity.

Keg and open container laws: In the United States, retailers may sell kegs of beer, but many states impose restrictions on the sale in the form of deposits and identification 
requirements. For example, kegs may be tagged with identifying information about the purchaser, and many states have laws preventing the destruction of these labels. These laws are designed to aid law enforcement efforts. Many states, but not all, also have "open container laws" that prohibit open containers (cans or bottles) of alcohol in vehicles. State laws vary as to the details of the prohibition, including whether the prohibition applies to the passenger and driver, and the type of beverage applicable. The U.S. Federal Government has provided states with incentives to adopt a set of six criteria that constitute the federal standard. We include as a policy variable an indicator for whether the state has adopted the federal standard in designing its open container law.

Drunk driving laws: The primary drunk driving law pertains to the blood alcohol concentration (BAC) limit for adults. The current BAC limit in all states is 0.08 , but this standard has changed over time from a previous limit of 0.10 . The last state to change its law was Minnesota in July of 2005. All states also currently have a much stricter, zero-tolerance policy for drinkers who are under the legal age of 21 . While we cannot use this particular policy because of lack of variation, we do observe variation in the penalty imposed by states on underage drinking and driving in the form of a suspension or revocation of driving privileges. Additional variation comes from differences in the age at which these penalties pertain. These are the variables named "Drivers license loss age 18 or 19" and "Drivers license loss age 21".

Serving and selling laws: It is common in the U.S. for underage drinkers to obtain false documentation (“fake IDs") with false birthdates to gain entrance to bars. The variable "Count of fake ID support" is the number of support provisions given to retailers to help identify these false documents. Examples include distinctive licenses for underage drinkers, incentives for using electronic license scanners, and allowances for seizing the fake ID and detaining the minor. 
States further have mandatory training laws for servers or provide incentives for voluntary training for preventing sales to minors or to intoxicated people. The presence or absence of these laws is found in the variables "Mandatory training" and "Incentives for voluntary training".

Underage laws: All states have laws prohibiting the possession of alcohol by minors and furnishing of alcohol to minors, but some states allow exceptions to these laws. Examples include furnishing by family members and possession when a family member is present. Exceptions to both laws may be applicable in different locations such as any private location or only in the home. Many states also have laws that impose liability for adults who host underage drinking parties (termed "Hosting policy"), and these laws come with exceptions similar to those for possession and furnishing.

The NCVS data identify the Metropolitan Statistical Area (MSA) in which respondents reside, so we merged the alcohol regulatory policies to the individuals' MSA and state of residence based on the date of interview. When MSAs cross state lines, we used a population weighted average of the alcohol policies from the relevant states.

\section{Methods}

The analytical framework starts with the proposition that violence is related to alcohol consumption. Considering the drinking habits and personal characteristics of both the potential criminal and victim gives the following equation for violence:

1) $\quad V=v\left(A_{i}, A_{j}, X_{i}, X_{j}, U_{i}, U_{j}\right)$.

Equation 1, termed the structural violence equation, shows that an act of violence (V) is a function of the alcohol consumption of the individual $\left(A_{i}\right)$ who is the potential victim, the alcohol consumption of other individuals $\left(\mathrm{A}_{\mathrm{j}}\right)$ who are the potential perpetrators, and other observed characteristics of individuals $\left(\mathrm{X}_{\mathrm{i}}, \mathrm{X}_{\mathrm{j}}\right)$ which affect the propensity towards violence or 
victimization such as age, gender, income, and employment status. Lastly, $\mathrm{U}_{\mathrm{i}}$ and $\mathrm{U}_{\mathrm{j}}$ represent individual-level or area-level factors which influence the propensity towards violence.

Alcohol consumption by the potential victim $\left(A_{i}\right)$ and the potential perpetrator $\left(A_{j}\right)$ can be expressed by similar demand functions:

2) $\mathrm{A}_{\mathrm{i}}=\mathrm{a}\left(\mathrm{P}_{\mathrm{A}}, \mathrm{E}, \mathrm{X}_{\mathrm{i}}, \mathrm{U}_{\mathrm{i}}\right)$,

2a) $\quad A_{j}=a\left(P_{A}, E, X_{j}, U_{j}\right)$,

where $\mathrm{P}_{\mathrm{A}}$ is the full price of alcohol, $\mathrm{E}$ are law enforcement variables which may affect consumption through the enforcement of alcohol related laws, and $\mathrm{X}$ and $\mathrm{U}$ are individual or area-level characteristics that may determine consumption. These sets of characteristics may be the same ones which determine violence. Given that the violent acts examined in this study require personal contact, the victim and the perpetrator will be located in close proximity and thus face the same full prices and law enforcement variables. The full price of alcohol reflects both the monetary price and other costs of obtaining the substance, such as time and travel costs. Substituting equations 2 and 2a into equation 1 gives a reduced form violence equation for either the victim or perpetrator:

3) $\quad V=v\left(P_{A}, E, X_{i}, X_{j}, U_{i}, U_{j}\right)$.

Equation 3 can be fully estimated empirically only when the characteristics of both the potential victim and perpetrator are observed. Unfortunately, most available data sets do not have full information on both. In light of this, a modified version of equation 3 serves as the basis for estimation when only limited characteristics are observed:

4) $\quad V=v\left(P_{A}, E, X, e\right)$,

where e is an error term that contains the unobserved characteristics of either the perpetrator or victim, and X represents any available individual-level characteristics. Including individual- 
level fixed effects will account for time-invariant, unmeasured characteristics in the error term, and omitted individual characteristics will not be problematic so long as these are uncorrelated with the components of the full price of alcohol, including the alcohol related laws, the variables of interest in this study.

The estimation of the reduced form equation, (equation 4), is particularly relevant to policy because the alcohol policy coefficients will show the propensity of increases in the full prices of alcohol to reduce violence. A negative coefficient on the beer price, for example, indicates that raising the price of beer is associated with reductions in violence, while a zero or positive coefficient shows that increasing the price will not reduce violent crime. We estimate the models using linear probability models with individual-level fixed effects and clustered standard errors by metropolitan statistical area (Bertrand et al. 2004).

The individual fixed effects models rely on sufficient temporal variation in the variables for proper estimation. Table 1 shows the average values of the policy variables that existed in the first and last years of the data. This table reveals clear changes in these averages over time, indicating the presence of intertemporal variation. Nevertheless, because the individual fixed effects are demanding, we present some alternative specifications below that include MSA level fixed effects rather than individual fixed effects.

The task of including and accounting for the variety of alcohol control policies is rather difficult given that we have collected sixteen different policies. We approach this in a variety of ways that are designed to minimize the potential for both omitted variable bias and multicollinearity. First, we specify a base equation that includes the price of beer and the number of liquor outlets per capita. These variables are chosen following from the previous 
literature, and because they represent the most popular regulations among states with the most variation across states and time.

We subsequently add other policy variables to the base models. The variables are described in Table 1, along with some summary statistics. Not all variables collected are presented in the tables of results below, although these additional results are available upon request. The models shown are those specifications that include policies related to keg purchases, drunk driving, selling and serving, Sunday sales, a count of the number of exceptions to underage laws, and whether state open container laws conform to federal standards.

The specific variables included in each model were chosen to minimize the potential for collinearity between the variables. However, these models may suffer from omitted variable bias, and we therefore develop alternative methods to include the alcohol policy variables. First, we generate an index that sums the dichotomous variables representing a restriction on alcohol and subtract the variables that represent a lack of restriction. In alternative specifications we test the sum of the restrictions and the sum of the lack of restrictions as separate indexes. Unfortunately, the indexes explain almost no variation in the outcomes and are rarely statistically significant, and therefore are not shown.

Our second alternative method of including the alcohol control policy variables is through the use of tetrachoric principal component analysis (TPCA). This procedure is a type of principal component analysis (PCA) designed for binary variables. As with standard PCA, the TPCA is a variable reduction method that extracts "principal components" as linear combinations of optimally-weighted observed variables. We conduct this analysis using the time period corresponding to that of the NCVS (1994-2004) and data from all 50 states. We generate new variables containing the extracted factors, the number of which depends on the resulting 
cumulative proportion of the explained variation (using 0.75 as a cutoff value). The factors are then included as variables in the regression models.

We show two models with the constructed factors. The first contains the factors from drunk driving laws, keg/open container laws, and selling and serving laws. The second contains a broader grouping of variables and represents the restrictive variables and exceptions to laws. The actual variables and their loading coefficients are shown in a table described below. The generated factors have low correlations with each other so including the factors from the different groupings of variables is not problematic.

In interpreting the results, we caution that there may be potential endogeneity problems with all the price and alcohol policy variables, to the extent that unobserved, time varying factors may be in the error term and correlated with both the policies and criminal violence. The fixed effects will help mitigate any time invariant correlation, and the TCPA also minimizes this potential correlation. Nevertheless, our results should be treated as correlations, and only be used for evidence for or against causality from alcohol consumption to violence.

\section{Results}

Table 2 shows summary statistics for the NCVS data. About 0.6 percent of the sample reports an assault in a six month period, and about 0.2 percent of the sample reports alcohol or drug involved assaults. The average real beer price measured in 1982-1984 dollars is \$3.64 per 6-pack. On average, there is one licensed liquor outlet for every 1,000 population, and about 30 percent of the sample requires information for keg purchases. About half of the states have laws pertaining to drunk driving, while fewer states impose mandatory training and other types of restrictions on sales and hosting. 
Table 3 shows the construction of the TPCA. Each grouping of alcohol control policies shows the number of factors extracted and how each policy loads into each factor. Higher absolute values of loadings indicate that the relevant policy accounts for more of the variation explained by the factor. Drunk driving laws split into two factors, with the first one loading most on the provisions for loss of drivers license and the second loading most on the 0.08 BAC law. Selling laws split into three principle components with requirements that sellers/servers are age 21 or over and training incentives loading mainly in the first factor, and different levels of fake ID support provisions loading into all the factors. Keg variables load into two factors, with all three policies loading fairly equally into the first factor and the keg deposit loading into the second factor. The group of restrictive policies loads into four factors and exceptions to alcohol laws load into two factors.

Tables 4 and 5 show the effects of beer prices and alcohol policies on self-reported assaults, and alcohol or drug related assaults, respectively, for individuals age 18 and over. The tables show marginal effects from linear probability models with individual fixed effects. Many of our coefficients are very small in magnitude, so we multiply all coefficients by 100 to ease the interpretation in all tables. T-statistics calculated from standard errors clustered at the MSA level are shown in parentheses. The dependent variable in each specification is an indicator variable for whether an individual was the victim of an assault in the previous 6 months.

In Table 4 the coefficients on the real beer price are negative, but statistically insignificant. The magnitude indicates that a $\$ 1.00$ increase in the real price of beer is associated with about a 0.07 percentage point decrease in an individual's probability of being assaulted in a 6 month period, or a reduction in the mean from 0.6 percent to 0.53 percent (representing about a 12 percent reduction in the mean). The coefficients on the alcohol policy variables are also small 
and mostly insignificant, and policies such as high keg deposits and mandatory serving or selling training requirements are associated with increased assaults, contrary to expectations. Only the variable representing conforming to federal standards regarding open container laws is negatively related to the probability of assaults.

Table 5 restricts the dependent variable to self-reported assaults involving observed alcohol or drug use by the offender. In Table 5 , the coefficients on the real beer price are negative, and although they are not statistically significant at the 5 percent level, the coefficients achieve statistical significance at the 10 percent level in a two-tailed test in all but one model. Here, a $\$ 1.00$ increase in the real beer price is associated with about a 0.06 percentage point decrease in an individual's probability of being assaulted in a 6 month period. This translates to a 30 percent reduction in alcohol or drug involved assaults off of the mean of 0.2 . The similarity in the magnitude of the marginal effects here and in Table 4 suggests that the results for all assault results are being driven primarily by that of alcohol and drug related assaults. This makes sense since the portion of assaults that are not related to alcohol consumption should not be altered by changes in an alcoholic beverage price. Most other alcohol control policies do not have much effect on alcohol or drug related assaults. As with the probability of assaults, mandatory serving or selling training requirements are associated with increased alcohol or drug related assaults. However, incentives for voluntary training are associated with decreased alcohol or drug related assaults.

We do note that the results for the alcohol or drug involved assaults should be interpreted with some caution. A change in an alcohol policy can cause a change in consumption and a corresponding change in violence, or may lead to a change in consumption without changing violence. Given the construction of this dependent variable, so long as alcohol consumption is 
reduced from a policy, both of these cases will be reflected in our results. It is difficult to know which case we observe, but to help figure it out, we run two supplementary analyses (available upon request). The first compares the probability of being a victim of drug and alcohol related violence to the group of non-victims only and the second compares the probability being a victim of drug and alcohol related violence to the group of victims who reported observing no drugs or alcohol involvement. The results of the first comparison are practically identical to those shown in the tables below. In the second comparison the beer price coefficients are statistically insignificant in all models. This provides some evidence that any reduction in consumption from a beer price change goes concurrently with a decrease in violence.

These results are generally confirmed by the TPCA shown in Table 6. The first two columns in Table 6 show results for all assaults, and here, the beer price is negative but not statistically significant. The second two columns show results for alcohol or drug related assaults. Here, the beer price coefficients are negative and of similar magnitude to the coefficients in Table 5 with the statistical significance hovering around the 10 percent level. As for the factors, a few are significant at the 10 percent level for all assaults (see the coefficients for selling, kegs, and restrictions). However, most signs are positive, reflecting some of the positive signs seen in Table 4. Only the coefficient on the first factor for restrictions is negative, indicating that restrictive policies as a group may be useful in reducing violence. Many of the policies load equally in to this factor (see Table 3), so it is difficult to attribute this effect to a few types of policies. This result also becomes a bit questionable as the third factor for restrictive policies displays a positive relationship with assaults. This third factor is also comprised of many of the same policies. 
The results for the TCPA coefficients in the models for alcohol or drug related assaults also yield mixed conclusions. Here, factors for selling and kegs are statistically significant, with selling and the second keg factor (which loads on the keg deposit) positive and significant, contrary to expectations. The first keg factor, which loads on all three keg policies, is negative and statistically significant, indicating that the combination of these restrictions may be effective in reducing alcohol or drug related assaults. However, the broader groupings of restricted policies show no statistical relationship with alcohol or drug related assaults.

In Table 7, we show select models for assault victimizations among those ages 18-29. The results are similar to the previous tables in that the coefficients on the beer price are negative for assaults and alcohol or drug related assaults but only nearly statistically significant for the latter outcome. The magnitudes are much larger, ranging from 0.2 to 0.4 percentage points. This provides some evidence that the results from the all victims sample are being driven primarily by the behaviors of the young adult sample. There are two other policies of interest in this table. The first is the coefficient on the number of licensed liquor outlets. This coefficient is positive and significant in both of the alcohol or drug related assault models, indicating that more outlets are associated with more of this type of violence. We caution that endogeneity may be a problem here if time-varying factors affect both the location of outlets and the occurrence of crime. However, the fixed effects address correlation in the error term from time invariant individual (and thus area) level sources. The second result of interest is the penalty of loss of drivers license up to age 21. The coefficients on this variable are negative and significant in both types of victimization models, indicating that this policy is associated with a reduction in drinking and violence among young people. Also of interest is that the broad groupings of restricted policies show no statistical relationship with either definition of assaults. 
The models for robbery corresponding to the assault models shown in Tables 4 through 7 were tested but are not shown for brevity, but are available upon request. In the individual fixed effects models, almost none of the alcohol policy coefficients are significant predictors of robbery victimizations. This statement holds for robbery victimization for all ages, ages 18-29, and for alcohol or drug involved robberies. These results are not surprising since robbery has a complex relationship with alcohol in that income producing crimes may be committed to support an alcohol habit. An inelastic demand for alcohol would result in a positive relationship between alcohol prices and robbery. This would mitigate any negative relationship between alcohol prices and the violent aspect of robbery. We refer the reader to Markowitz (2005) for a complete discussion of this issue.

Next, we show alternative models that include MSA level fixed effects in place of the individual level fixed effects. This should add in more "within" variation to the models and more efficient estimation. For brevity, we show only select models similar to those in Table 7. The full set of models as specified in Table 4 are available upon request. The results in Table 8 are consistent with those in the previous tables. The coefficients on the beer price remain negative, are of similar magnitude to that in the previous tables, and the standard errors decrease. The beer price coefficients for all assaults are still insignificant at conventional levels, however, the beer price coefficients in the alcohol and drug related models that were previously significant only at the 10 percent level and are now significant at the 5 percent level or better. Some of the other policy coefficients also achieve statistical significance, such as liquor outlets for the alcohol and drug related assaults. However, there are some other coefficients in the table that achieve statistical significance, but exhibit a sign that is contrary to expectations (e.g. drivers license loss age 21 has a positive and significant coefficient in the all assaults model). These 
results add to our overall conclusion that the beer price has the strongest association with violent victimization, and few of the other alcohol control policies, if any, are successful in reducing violence.

Using MSA-level fixed effects rather than individual level fixed effects for the 18-29 year old sample also does little to change the results. The magnitude of the beer price effect is still large, but is significant in only one specification and only at the 10 percent level. Outlets are positively associated with the probability of victimization, but in Table 8, the significance level decreases to around the 10 percent level. Also, the coefficient on the loss of drivers license at age 21 as a penalty for drunk driving switches sign using the MSA fixed effects. This casts some doubt on the validity of this result from the individual fixed effects models.

\section{Conclusion}

This paper provides new evidence of the relationships between alcohol prices, alcohol policies and crime in the United States. We examine self-reported victimization data to estimate the occurrence of violence that is both reported and not reported to authorities. This data also allows us to identify the crimes that are related to alcohol consumption and therefore more likely to be affected by changes in alcohol control policies. We also examine the effects of policies on violent victimization among young adults ages 18-29. This is the age group that is most likely to be involved in criminal activity (accounting for 40 to 48 percent of all arrests in any given year). ${ }^{3}$

We combine the measure of violence with a large number of alcohol control policies that varied considerably over the 1990s and early 2000s. We enter the policies directly in the regressions and indirectly through a principal components analysis. Results from either method corroborate each other. However, there are a few limitations to our study. First, we only

\footnotetext{
${ }^{3}$ Authors' calculations from the Uniform Crime Reports.
} 
examine self-reports of violent victimization. The data do not include information on perpetration, or events where violence may be reciprocal, such as fights. Second, the fixed effects are valid for capturing unobserved, time invariant factors that may confound the relationship between alcohol policies and violence. However, we will not capture time varying effects, although given the short time period represented by the fixed effects (three years), this should not be a problem.

Our overall conclusion from this paper is that an increase in the beer price, which can be achieved through increased taxes, is the most effective of all the alcohol control policies to reduce violence. However, beer taxes are excise taxes that are a fixed dollar amount per volume of alcohol, and there have been very few states that have increased these taxes in recent years. This has contributed to an overall drop in real beer prices over the period of our study. Our results imply that an increase in excise taxes could lead to a reduction in assaults. However, our price effects are only significant at conventional levels when considering the probability of an alcohol or drug involved assault.

Few conclusions can be drawn for the other alcohol control policies. Some of the observed relationships include the following: 1) The loss of drivers license up to age 21 as a penalty for drunk driving is negatively associated with violent victimization among young adults. 2) Open container laws that meet federal standards are associated with a reduced probability of assault victimization. 3) The presence of incentives for voluntary beverage server training programs are associated with a reduced probability of assault victimization, although mandatory training is unexpectedly positively associated with the probability of assault victimization. It is not clear why a positive relationship would exist. This is a question for future research. 
The factor analysis used to condense and summarize the policies is more informative than the mixed results from the policies themselves. We find that on the whole, the group of restrictive alcohol beverage control policies are ineffective in altering violence rates. While some policies may be effective in reducing the demand for alcohol, or in reducing other undesirable outcomes related to drinking, such as drunk driving, our results show that broadly summarized restrictive policies are not associated with reductions in violence. Increases in the beer price through increases in excise taxes are likely to be much more effective in reducing violence than other forms of alcohol beverage control. 


\section{REFERENCES}

Adams Beverage Group. [various years] Adams Liquor Handbook, Adams Media Inc., New York, NY.

Beer Institute. [various years] Brewers' Almanac, United States Brewers Foundation, New York, NY.

Bertrand, M., E. Duflo, et al. (2004), "How Much Should We Trust Differences-in-Differences Estimates?", Quarterly Journal of Economics 119(1), 249-275.

Biderman, Ciro, Joao M. P. De Mello, and Alexandre Schneider (2010), "Dry Laws and Homicides: Evidence from the Sao Paulo Metropolitan Area", The Economic Journal, 120:543, 157-182.

Cameron, Colin A and Pravin K. Trivedi (2009), Microeconometrics. Using Stata, StataCorp LP, Stata Press, College Station, TX.

Carpenter, Christopher (2007), "Heavy Alcohol Use and Crime: Evidence from Underage Drunk Driving Laws", Journal of Law and Economics 50(3), 539-557.

Carpenter, Christopher and Carlos Dobkin (2010), “Alcohol Regulation And Crime”, NBER working paper 15828.

Chaloupka, F.J., and H. Saffer (1992), “Alcohol, Illegal Drugs, Public Policy and Crime”, Presented at the annual meeting of the Western Economic Association, San Francisco, CA.

Chikritzhs, T. and T. Stockwell (2002), "The impact of later trading hours for Australian public houses (hotels) on levels of violence", Journal of Studies on Alcohol 63, 591-599.

Cnossen Sijbren (2007), "Alcohol taxation and regulation in the European Union", Int Tax Public Finance 14, 699-732.

Cook, Philip J. (2007), Paying the Tab: The Costs and Benefits of Alcohol Control, Princeton University Press, Princeton, NJ.

Cook, P.J., and M.J. Moore (1993), "Economic Perspectives on Reducing Alcohol-Related Violence”, in: S.E. Martin (eds.), Alcohol and Interpersonal Violence: Fostering Multidisciplinary Perspectives, National Institute on Alcohol Abuse and Alcoholism Research Monograph 24, NIH Publication No. 93-3469, Washington, DC: U.S. Government Printing Office, 193-211.

Cook, P.J and G. Tauchen (1982), “The Effect of Minimum Drinking Age Legislation on Youthful Auto Fatalities, 1970-1977”, Bell Journal of Economics 13(2), 379-390.

Desimone, J. (2001), "The effect of cocaine prices on crime", Economic Inquiry 39(4), 627-643. 
Goldstein, P.J. (1985), “The Drugs/Violence Nexus: A Tripartite Conceptual Framework”, Journal of Drug Issues 15, 493-506.

Grossman M. and S. Markowitz (2001), “Alcohol Regulation and Violence on College Campuses”, in: M. Grossman and C.R. Hsieh (eds.), Economics of Substance Abuse, United Kingdom, Edward Elgar Limited.

Gyimah-Brempong, K (2001), “Alcohol Availability and Crime: Evidence from Census Tract Data”, Southern Economic Journal 68(1), 2-21.

Olsson, O. and P. Wikstrom (1982), "Effects of the experimental Saturday closing of liquor retail stores in Sweden", Contemporary Drug Problems 11, 325-353.

Markowitz, S. (2000), “The Price of Alcohol, Wife Abuse and Husband Abuse”, Southern Economic Journal 67(2), 279-303.

Markowitz, S. (2005) “Alcohol, Drugs and Violent Crime”, International Review of Law and Economics 25(1), 20-44.

Markowitz, S and M Grossman (1998), “Alcohol Regulation and Domestic Violence Towards Children”, Contemporary Economic Policy 16(3), 309-320.

Markowitz, S and M Grossman (2000), “The Effects of Beer Taxes on Physical Child Abuse”, Journal of Health Economics 19(2), 271-282.

Markowitz, S, P Chatterji, and R Kaestner (2003) (2005), "Estimating the Impact of Alcohol Policies on Youth Suicide”, Journal of Mental Health Policy and Economics 6(1), 37-46, Economics 25(1), 20-44.

Matthews, K., Shepherd, J., Sivarajasingham, V. (2006), "Violence related injury and the price of beer in England and Wales”, Applied Economics 38, 661-670.

Ruhm, Christopher J., Alison Snow Jones, William C. Kerr, et al. "What U.S. Data Should Be Used To Measure The Price Elasticity Of Demand For Alcohol?" NBER Working Paper No. 17578. November 2011.

Scribner, R. A.; D.P. MacKinnon; and J.H. Dwyer (1995), "The Risk of Assaultive Violence and Alcohol Availability in Los Angeles County", American Journal of Public Health 85, 335-340.

Scribner, R.A., D. Cohen, S. Kaplan and S.H. Allen (1999), "Alcohol Availability and Homicide in New Orleans: Conceptual Considerations for Small Area Analysis of the Effect of Alcohol Outlet Density", Journal of Studies on Alcohol 60(3), 310-316.

Sloan, Frank A.; Emily M. Stout, Katheryn Whetten-Goldstein, and Lan Liang (2000), Drinkers, Drivers, and Bartenders: Balancing Private Choices and Public Accountability, The University of Chicago Press, Chicago. 
U.S. Department of Health and Human Services (2011), Healthy People 2020. Available at: http://www.healthypeople.gov/2020/topicsobjectives2020/default.aspx. [downloaded May 2 2011].

Centers for Disease Control and Prevention. Web-based Injury Statistics Query and Reporting System (WISQARS) [Online]. (2003). National Center for Injury Prevention and Control, Centers for Disease Control and Prevention (producer). Available from: URL:

www.cdc.gov/ncipc/wisqars. [accessed Feb. 3 2011].

World Health Organization, Global Status Report on Alcohol (2004). Available at:

http://www.who.int/substance_abuse/publications/global_status_report_2004_overview.pdf.

[downloaded May 2 2011].

Young DJ, Bielinska-Kwapisz A. “Alcohol Taxes and Beverage Prices.” National Tax Journal, March 2002, 57-73.

Young DJ, Bielinska-Kwapisz A. “Alcohol Consumption, Beverage Prices and Measurement Error.” Journal of Studies on Alcohol, 2003, 64(2): 235-8. 


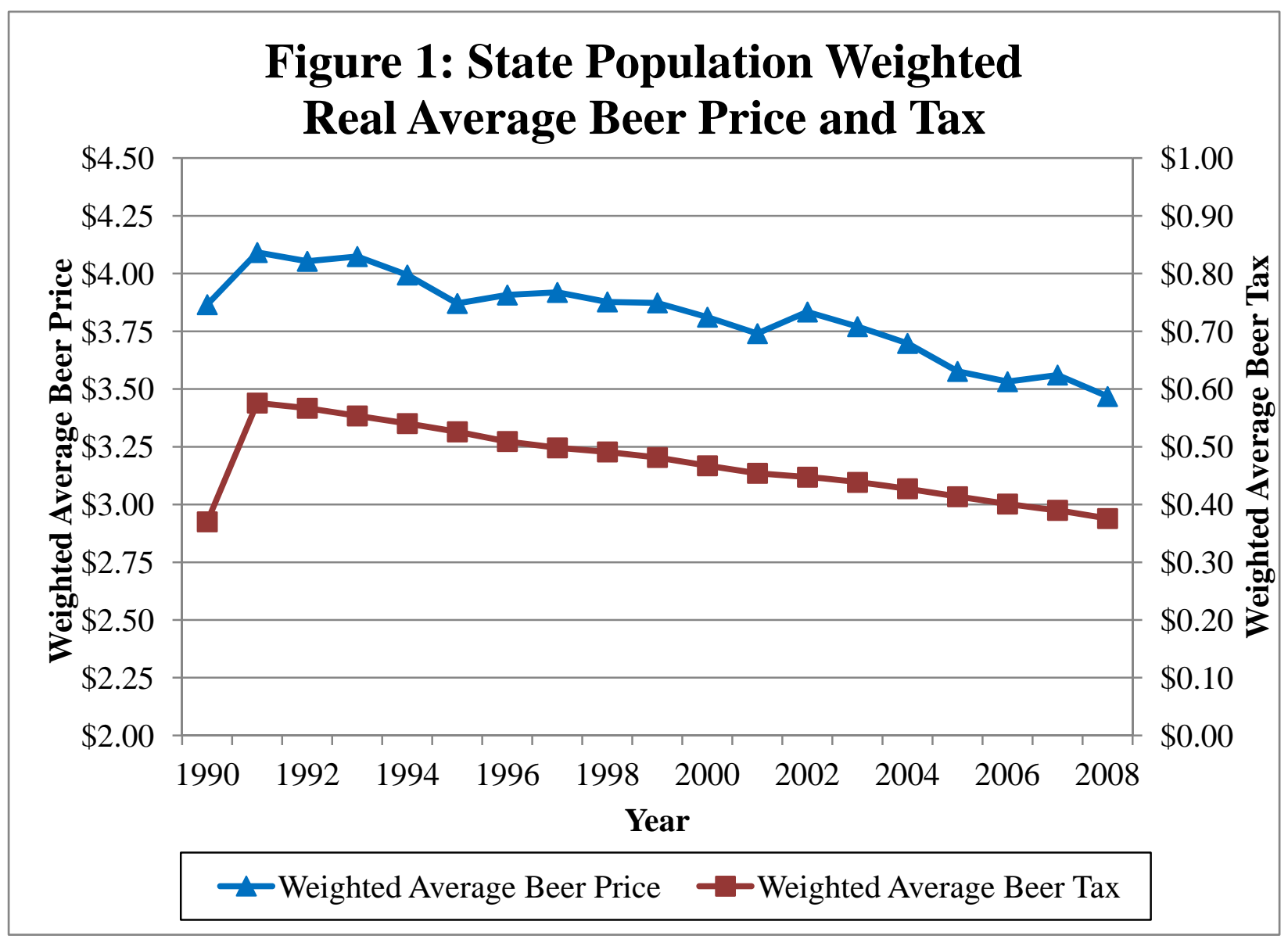


Figure 2: MSA Real Average Beer Price
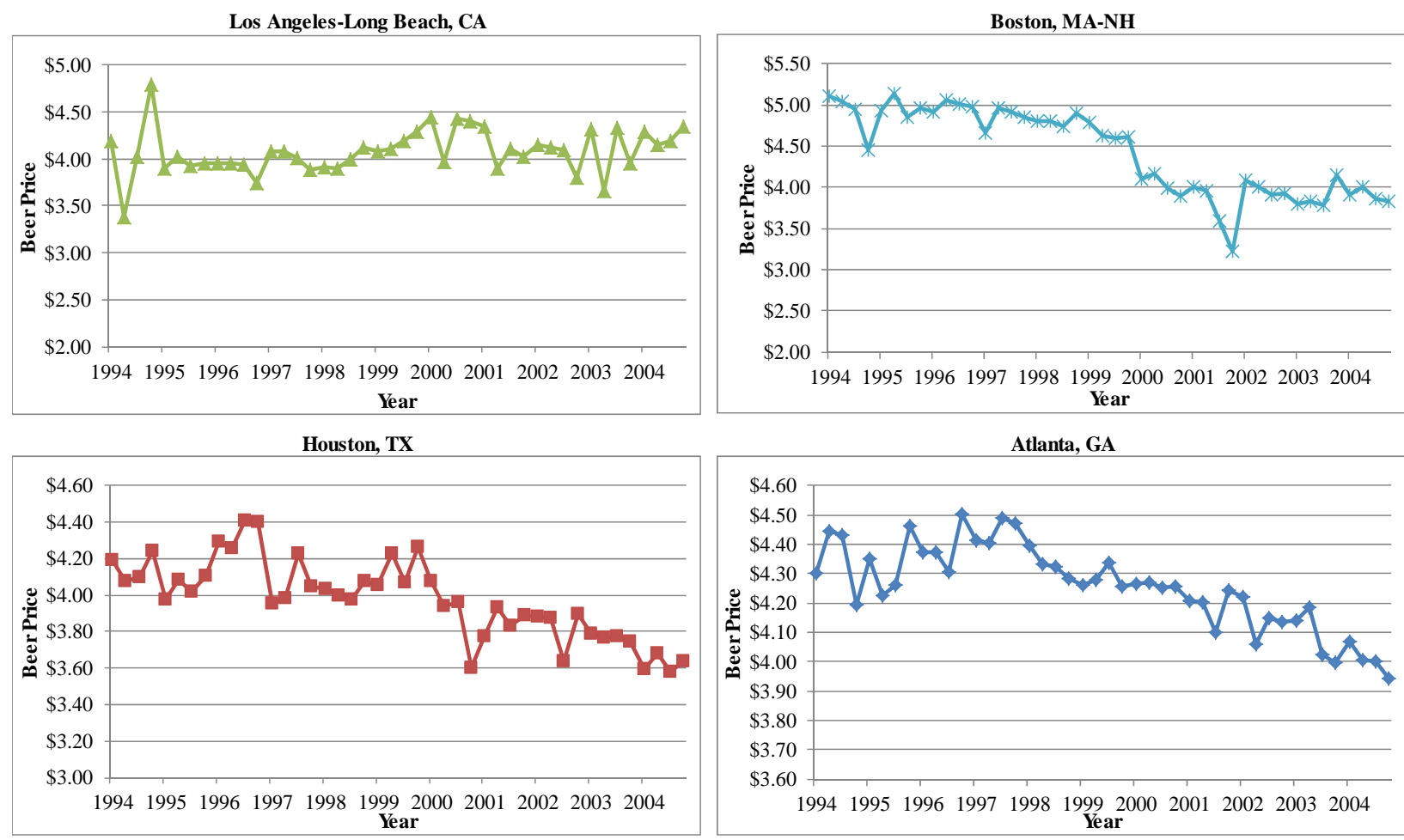
Table 1: Alcohol Policy Descriptions (Number MSAs = 40)

\begin{tabular}{|c|c|c|c|}
\hline & & $\begin{array}{c}\text { Mean } \\
\text { In } 1994 \\
\end{array}$ & $\begin{array}{c}\text { Mean } \\
\text { In } 2004 \\
\end{array}$ \\
\hline Price and availability & Definition & & \\
\hline Real beer price & ACCRA price of a six pack of beer in $\$ 1982-1984$ & 3.885 & 3.608 \\
\hline Liquor outlets & Number licensed liquor outlets per 1000 pop. & 1.250 & 1.167 \\
\hline \multicolumn{4}{|l|}{ Keg and open container laws } \\
\hline Keg info required & $\begin{array}{l}\text { State requires information regarding purchaser's id } \\
\text { or location before purchase of keg }\end{array}$ & 0.200 & 0.375 \\
\hline Keg deposit* & Keg deposit in dollars (range $=0$ to $\$ 75$ ) & 0.000 & 3.750 \\
\hline Prohibit unlabeled keg & $\begin{array}{l}\text { State prohibits possession of an unlabeled keg or } \\
\text { destroying the label on a keg }\end{array}$ & 0.200 & 0.350 \\
\hline Open container federal standard & $\begin{array}{l}\text { State open container laws conform to federal } \\
\text { standard }\end{array}$ & 0.000 & 0.050 \\
\hline \multicolumn{4}{|l|}{ Drunk Driving Laws } \\
\hline BAC .08 & Blood alcohol content level of 0.08 & 0.176 & 0.962 \\
\hline Drivers license loss age 18 or 19 & $\begin{array}{l}\text { State penalty for underage drinking and driving is } \\
\text { loss of drivers license until age } 18 \text { or } 19\end{array}$ & 0.300 & 0.200 \\
\hline Drivers license loss age 21 & $\begin{array}{l}\text { State penalty for underage drinking and driving is } \\
\text { loss of drivers license until age } 21\end{array}$ & 0.400 & 0.550 \\
\hline \multicolumn{4}{|l|}{ Serving and Selling Laws } \\
\hline Count of fake ID support* & $\begin{array}{l}\text { Number of support provisions for retailers for } \\
\text { identifying fake ids (range }=0 \text { to } 4 \text { ) }\end{array}$ & 1.900 & 2.250 \\
\hline Age 21 to serve or sell** & $\begin{array}{l}\text { State specifies a minimum age of } 21 \text { to sell or serve } \\
\text { alcohol }\end{array}$ & 0.050 & 0.050 \\
\hline Mandatory training & $\begin{array}{l}\text { State requires mandatory beverage service training } \\
\text { for employer or server }\end{array}$ & 0.150 & 0.300 \\
\hline Incentives for voluntary training & $\begin{array}{l}\text { State provides incentives for voluntary beverage } \\
\text { service training }\end{array}$ & 0.150 & 0.300 \\
\hline \multicolumn{4}{|l|}{ Sunday Sales } \\
\hline Sunday ban & State bans sale of all types of alcohol on Sunday & 0.200 & 0.150 \\
\hline \multicolumn{4}{|l|}{ Underage laws } \\
\hline Possession exception & State has exceptions to underage possession laws & 0.450 & 0.650 \\
\hline Furnishing exception & State has exceptions to furnishing to minors laws & 0.550 & 0.550 \\
\hline Hosting exception & State has exceptions to hosting laws & 0.250 & 0.337 \\
\hline Count of exceptions & $\begin{array}{l}\text { Count of number of exceptions to underage laws } \\
\text { (range }=0 \text { to } 3 \text { ) }\end{array}$ & 1.250 & 1.537 \\
\hline Hosting policy & $\begin{array}{l}\text { State has a policy regarding hosting underage } \\
\text { parties }\end{array}$ & 0.500 & 0.587 \\
\hline
\end{tabular}

*Variable dichotomized for TPCA analysis.

**There is variation in this variable when considering all 50 states, thus this variable is included in the TPCA but is not used in the policy-specific models. 
Table 2: Summary Statistics for NCVS Data

\begin{tabular}{|c|c|c|}
\hline & Mean & $\begin{array}{l}\text { Std. } \\
\text { Dev. }\end{array}$ \\
\hline \multicolumn{3}{|l|}{ Dependent Variables } \\
\hline Assault victim & 0.006 & 0.076 \\
\hline Alcohol-involved assault victim & 0.002 & 0.045 \\
\hline Assault victim ages $18-29$ & 0.012 & 0.11 \\
\hline Alcohol-involved assault victim ages 18-29 & 0.007 & 0.081 \\
\hline \multicolumn{3}{|l|}{ Select Alcohol Control Variables } \\
\hline Real beer price & 3.64 & 0.72 \\
\hline Liquor outlets per 1000 population & 1.04 & 0.49 \\
\hline Keg info required & 0.29 & 0.45 \\
\hline Keg deposit & 0.76 & 7.52 \\
\hline BAC .08 & 0.51 & 0.50 \\
\hline Drivers license loss age 18 or 19 & 0.18 & 0.38 \\
\hline Drivers license loss age 21 & 0.53 & 0.50 \\
\hline Mandatory training & 0.10 & 0.30 \\
\hline Incentives for voluntary training & 0.33 & 0.47 \\
\hline Hosting policy & 0.38 & 0.49 \\
\hline Sunday ban & 0.14 & 0.35 \\
\hline Count of exceptions & 1.19 & 0.85 \\
\hline Open container federal standard & 0.60 & 0.49 \\
\hline \multicolumn{3}{|l|}{ State Demographics } \\
\hline Percent rural & 18.70 & 12.18 \\
\hline Unemployment rate & 5.39 & 1.13 \\
\hline Percent with bachelor's degree & 25.41 & 4.07 \\
\hline Real income per capita, in $\$ 1000$ s & 16.70 & 1.92 \\
\hline Percent population age 15 to 24 & 13.82 & 0.84 \\
\hline Percent population black & 11.97 & 6.82 \\
\hline Lagged per capita expenditures on police & 198.09 & 61.25 \\
\hline Lagged incarceration rate & 417.64 & 133.35 \\
\hline \multicolumn{3}{|l|}{ Individual Characteristics } \\
\hline Age 25 to 29 & 0.09 & 0.28 \\
\hline Age 30 to 49 & 0.44 & 0.50 \\
\hline Age 50 and up & 0.38 & 0.48 \\
\hline Married & 0.59 & 0.49 \\
\hline Less than high school education & 0.39 & 0.49 \\
\hline High school education & 0.30 & 0.46 \\
\hline College education & 0.53 & 0.50 \\
\hline Income less than $\$ 7,500$ & 0.04 & 0.19 \\
\hline Income $\$ 7,500$ to $\$ 24,999$ & 0.10 & 0.30 \\
\hline Income $\$ 25,000$ to $\$ 29,999$ & 0.05 & 0.21 \\
\hline Income $\$ 30,000$ to $\$ 49,999$ & 0.19 & 0.39 \\
\hline
\end{tabular}




\begin{tabular}{|lll|} 
Income $\$ 50,000$ and over & 0.35 & 0.48 \\
Income missing & 0.21 & 0.41 \\
\hline
\end{tabular}

Notes: $\mathrm{N}=542,353$ for all variables except for alcohol or drug involved assault victimizations, where $\mathrm{N}=538,440$, assaults for victims age $18-29$, where $\mathrm{N}=96,739$, and alcohol or drug involved assault victimizations for victims age 18-29, where $\mathrm{N}=95,508$. 
Table 3: Tetrachoric Principal Component Analysis Loading Coefficients

\begin{tabular}{|lcccc|}
\hline & \multicolumn{5}{c|}{ NCVS Data 1994-2004 } \\
\hline & Factor & Factor & Factor & Factor \\
\hline Drunk Driving Laws & $\mathbf{1}$ & $\mathbf{2}$ & $\mathbf{3}$ & $\mathbf{4}$ \\
\hline BAC .08 & & & & \\
Drivers license loss age 18 or 19 & 0.194 & 0.967 & & \\
Drivers license loss age 21 & -0.682 & 0.253 & & \\
& 0.705 & -0.021 & & \\
Serving and Selling Laws & & & & \\
Fake ID support: 1 provision & & & & \\
Fake ID support: 2 provisions & -0.397 & -0.620 & 0.134 & \\
Fake ID support: 3 or 4 provisions & 0.565 & -0.058 & -0.538 & \\
Age 21 to serve or sell & -0.164 & 0.672 & 0.414 & \\
Mandatory training & 0.299 & -0.289 & 0.579 & \\
Incentives for voluntary training & 0.380 & 0.206 & 0.093 & \\
& -0.512 & 0.186 & -0.422 & \\
Keg Laws & & & & \\
Keg info required & & & & \\
Presence of keg deposit & 0.657 & -0.090 & & \\
Prohibit unlabeled keg & 0.485 & 0.810 & & \\
& 0.577 & -0.579 & & \\
Restrictive Policies & & & & \\
Age 21 to serve or sell & & & & \\
Mandatory training & -0.457 & 0.613 & & \\
Incentives for voluntary training & -0.006 & 0.326 & -0.418 & -0.334 \\
Sunday ban & -0.342 & 0.138 & 0.304 & 0.027 \\
Hosting policy & 0.378 & 0.250 & -0.416 & 0.350 \\
Open container federal standard & 0.273 & -0.031 & -0.038 & 0.312 \\
Prohibit unlabeled keg & 0.505 & 0.047 & 0.341 & -0.298 \\
Keg info required & 0.416 & -0.035 & 0.540 & -0.263 \\
Drivers license loss age 21 & -0.115 & 0.525 & 0.328 & 0.280 \\
Drivers license loss age 18 or 19 & 0.214 & -0.528 & -0.155 & -0.095 \\
& & & & \\
Exceptions & -0.314 & -0.495 & 0.122 & 0.201 \\
Possession exception & & & & \\
Furnishing exception & 0.531 & & \\
Hosting exception & -0.294 & & \\
Sunday local & -0.101 & -0.063 & 0.618 \\
\hline
\end{tabular}


Table 4: NCVS Regressions for All Assault Victimizations

\begin{tabular}{|c|c|c|c|c|c|c|c|c|}
\hline & $\begin{array}{c}\text { Model } \\
1 \\
\end{array}$ & $\begin{array}{c}\text { Model } \\
2 \\
\end{array}$ & $\begin{array}{c}\text { Model } \\
3 \\
\end{array}$ & $\begin{array}{c}\text { Model } \\
4 \\
\end{array}$ & $\begin{array}{c}\text { Model } \\
5 \\
\end{array}$ & $\begin{array}{c}\text { Model } \\
6 \\
\end{array}$ & $\begin{array}{c}\text { Model } \\
7 \\
\end{array}$ & $\begin{array}{c}\text { Model } \\
8 \\
\end{array}$ \\
\hline Real beer price & $\begin{array}{c}-0.071 \\
(-1.172)\end{array}$ & $\begin{array}{c}-0.072 \\
(-1.171)\end{array}$ & $\begin{array}{c}-0.075 \\
(-1.201)\end{array}$ & $\begin{array}{c}-0.072 \\
(-1.176)\end{array}$ & $\begin{array}{c}-0.061 \\
(-0.963)\end{array}$ & $\begin{array}{c}-0.071 \\
(-1.172)\end{array}$ & $\begin{array}{c}-0.071 \\
(-1.167)\end{array}$ & $\begin{array}{c}-0.071 \\
(-1.119)\end{array}$ \\
\hline Liquor outlets & $\begin{array}{c}0.042 \\
(0.457)\end{array}$ & $\begin{array}{c}0.043 \\
(0.466)\end{array}$ & $\begin{array}{c}0.045 \\
(0.483)\end{array}$ & $\begin{array}{c}0.045 \\
(0.495)\end{array}$ & $\begin{array}{c}0.049 \\
(0.571)\end{array}$ & $\begin{array}{c}0.041 \\
(0.450)\end{array}$ & $\begin{array}{c}0.038 \\
(0.424)\end{array}$ & $\begin{array}{c}0.094 \\
(0.967)\end{array}$ \\
\hline Keg info required & & $\begin{array}{c}0.069 \\
(0.773)\end{array}$ & & & & & & \\
\hline Keg deposit & & & $\begin{array}{c}0.003 \\
(2.837)\end{array}$ & & & & & \\
\hline BAC08 & & & & $\begin{array}{c}0.027 \\
(0.497)\end{array}$ & & & & \\
\hline Drivers license loss age 18 or 19 & & & & $\begin{array}{c}0.029 \\
(0.190)\end{array}$ & & & & \\
\hline Drivers license loss age 21 & & & & $\begin{array}{c}0.108 \\
(1.150)\end{array}$ & & & & \\
\hline Mandatory training & & & & & $\begin{array}{c}0.419 \\
(2.152)\end{array}$ & & & \\
\hline Incentives for voluntary training & & & & & $\begin{array}{c}-0.179 \\
(-1.566)\end{array}$ & & & \\
\hline Fake ID support & & & & & $\begin{array}{c}-0.108 \\
(-1.303)\end{array}$ & & & \\
\hline Sunday ban & & & & & & $\begin{array}{c}0.050 \\
(0.773)\end{array}$ & & \\
\hline Count of exceptions & & & & & & & $\begin{array}{c}-0.122 \\
(-1.376)\end{array}$ & \\
\hline Open container federal standard & & & & & & & & $\begin{array}{c}-0.222 \\
(-2.899)\end{array}$ \\
\hline Age 25 to 29 & $\begin{array}{c}-0.333 \\
(-1.373)\end{array}$ & $\begin{array}{c}-0.333 \\
(-1.373)\end{array}$ & $\begin{array}{c}-0.333 \\
(-1.372)\end{array}$ & $\begin{array}{c}-0.334 \\
(-1.375)\end{array}$ & $\begin{array}{c}-0.333 \\
(-1.371)\end{array}$ & $\begin{array}{c}-0.333 \\
(-1.373)\end{array}$ & $\begin{array}{c}-0.333 \\
(-1.372)\end{array}$ & $\begin{array}{c}-0.332 \\
(-1.368)\end{array}$ \\
\hline Age 30 to 49 & $\begin{array}{c}-0.511 \\
(-1.870)\end{array}$ & $\begin{array}{c}-0.511 \\
(-1.870)\end{array}$ & $\begin{array}{c}-0.511 \\
(-1.870)\end{array}$ & $\begin{array}{c}-0.511 \\
(-1.873)\end{array}$ & $\begin{array}{c}-0.510 \\
(-1.867)\end{array}$ & $\begin{array}{c}-0.511 \\
(-1.870)\end{array}$ & $\begin{array}{c}-0.511 \\
(-1.868)\end{array}$ & $\begin{array}{c}-0.508 \\
(-1.855)\end{array}$ \\
\hline Age 50 and up & $\begin{array}{c}-0.427 \\
(-1.552)\end{array}$ & $\begin{array}{c}-0.427 \\
(-1.553)\end{array}$ & $\begin{array}{c}-0.428 \\
(-1.554)\end{array}$ & $\begin{array}{c}-0.428 \\
(-1.559)\end{array}$ & $\begin{array}{c}-0.426 \\
(-1.548)\end{array}$ & $\begin{array}{c}-0.427 \\
(-1.551)\end{array}$ & $\begin{array}{c}-0.427 \\
(-1.549)\end{array}$ & $\begin{array}{c}-0.423 \\
(-1.535)\end{array}$ \\
\hline Married & $\begin{array}{c}-0.230 \\
(-2.772)\end{array}$ & $\begin{array}{c}-0.230 \\
(-2.774)\end{array}$ & $\begin{array}{c}-0.230 \\
(-2.772)\end{array}$ & $\begin{array}{c}-0.230 \\
(-2.772)\end{array}$ & $\begin{array}{c}-0.230 \\
(-2.779)\end{array}$ & $\begin{array}{c}-0.230 \\
(-2.774)\end{array}$ & $\begin{array}{c}-0.229 \\
(-2.764)\end{array}$ & $\begin{array}{c}-0.229 \\
(-2.768)\end{array}$ \\
\hline Less than high school education & $\begin{array}{c}0.118 \\
(1.610)\end{array}$ & $\begin{array}{c}0.118 \\
(1.608)\end{array}$ & $\begin{array}{c}0.118 \\
(1.609)\end{array}$ & $\begin{array}{c}0.118 \\
(1.624)\end{array}$ & $\begin{array}{c}0.118 \\
(1.610)\end{array}$ & $\begin{array}{c}0.117 \\
(1.598)\end{array}$ & $\begin{array}{c}0.118 \\
(1.610)\end{array}$ & $\begin{array}{c}0.119 \\
(1.621)\end{array}$ \\
\hline High school education & $\begin{array}{c}0.052 \\
(0.626)\end{array}$ & $\begin{array}{c}0.052 \\
(0.624)\end{array}$ & $\begin{array}{c}0.052 \\
(0.627)\end{array}$ & $\begin{array}{c}0.052 \\
(0.625)\end{array}$ & $\begin{array}{c}0.052 \\
(0.625)\end{array}$ & $\begin{array}{c}0.052 \\
(0.629)\end{array}$ & $\begin{array}{c}0.052 \\
(0.628)\end{array}$ & $\begin{array}{c}0.053 \\
(0.632)\end{array}$ \\
\hline College education & $\begin{array}{c}0.254 \\
(2.973)\end{array}$ & $\begin{array}{c}0.254 \\
(2.969)\end{array}$ & $\begin{array}{c}0.254 \\
(2.977)\end{array}$ & $\begin{array}{c}0.254 \\
(2.973)\end{array}$ & $\begin{array}{c}0.254 \\
(2.970)\end{array}$ & $\begin{array}{c}0.254 \\
(2.965)\end{array}$ & $\begin{array}{c}0.254 \\
(2.975)\end{array}$ & $\begin{array}{c}0.255 \\
(2.985)\end{array}$ \\
\hline Income less than $\$ 7,500$ & 0.077 & 0.077 & 0.077 & 0.077 & 0.076 & 0.077 & 0.077 & 0.076 \\
\hline
\end{tabular}




\begin{tabular}{|c|c|c|c|c|c|c|c|c|}
\hline & $(0.394)$ & $(0.394)$ & $(0.393)$ & $(0.392)$ & $(0.389)$ & $(0.394)$ & $(0.395)$ & $(0.390)$ \\
\hline \multirow[t]{2}{*}{ Income $\$ 7,500$ to $\$ 24,999$} & 0.006 & 0.006 & 0.006 & 0.006 & 0.006 & 0.006 & 0.006 & 0.005 \\
\hline & $(0.050)$ & $(0.050)$ & $(0.049)$ & $(0.049)$ & $(0.052)$ & $(0.050)$ & $(0.054)$ & $(0.043)$ \\
\hline \multirow[t]{2}{*}{ Income $\$ 25,000$ to $\$ 29,999$} & 0.149 & 0.149 & 0.149 & 0.148 & 0.149 & 0.149 & 0.149 & 0.149 \\
\hline & $(1.454)$ & $(1.452)$ & $(1.455)$ & $(1.449)$ & $(1.462)$ & $(1.454)$ & $(1.458)$ & $(1.462)$ \\
\hline \multirow[t]{2}{*}{ Income $\$ 30,000$ to $\$ 49,999$} & 0.022 & 0.022 & 0.023 & 0.022 & 0.022 & 0.022 & 0.023 & 0.022 \\
\hline & $(0.186)$ & $(0.184)$ & $(0.187)$ & $(0.182)$ & $(0.182)$ & $(0.186)$ & $(0.189)$ & $(0.181)$ \\
\hline \multirow[t]{2}{*}{ Income $\$ 50,000$ and over } & 0.011 & 0.011 & 0.011 & 0.011 & 0.011 & 0.011 & 0.011 & 0.010 \\
\hline & $(0.104)$ & $(0.102)$ & $(0.105)$ & $(0.101)$ & $(0.101)$ & $(0.104)$ & $(0.104)$ & $(0.098)$ \\
\hline \multirow[t]{2}{*}{ Income missing } & -0.090 & -0.089 & -0.089 & -0.090 & -0.090 & -0.090 & -0.089 & -0.091 \\
\hline & $(-0.896)$ & $(-0.895)$ & $(-0.890)$ & $(-0.895)$ & $(-0.908)$ & $(-0.897)$ & $(-0.893)$ & $(-0.916)$ \\
\hline \multirow[t]{2}{*}{ Unemployment } & 0.035 & 0.033 & 0.031 & 0.034 & 0.016 & 0.035 & 0.036 & 0.028 \\
\hline & $(0.462)$ & $(0.448)$ & $(0.421)$ & $(0.458)$ & $(0.192)$ & $(0.475)$ & $(0.486)$ & $(0.374)$ \\
\hline \multirow[t]{2}{*}{ Real income per capita, in $\$ 1000$ s } & 0.114 & 0.109 & 0.097 & 0.106 & 0.129 & 0.116 & 0.115 & 0.096 \\
\hline & $(0.974)$ & $(0.935)$ & $(0.824)$ & $(0.882)$ & $(1.116)$ & $(0.985)$ & $(0.976)$ & $(0.863)$ \\
\hline \multirow[t]{2}{*}{ Percent population age 15 to 24} & 0.178 & 0.174 & 0.165 & 0.175 & 0.199 & 0.185 & 0.176 & 0.232 \\
\hline & $(1.305)$ & $(1.271)$ & (1.169) & $(1.264)$ & $(1.515)$ & $(1.328)$ & $(1.282)$ & (1.663) \\
\hline \multirow[t]{2}{*}{ Percent population black } & -0.205 & -0.198 & -0.176 & -0.190 & -0.221 & -0.204 & -0.227 & -0.160 \\
\hline & $(-0.880)$ & $(-0.848)$ & $(-0.729)$ & $(-0.789)$ & $(-0.936)$ & $(-0.875)$ & $(-0.926)$ & $(-0.666)$ \\
\hline \multirow[t]{2}{*}{ Lagged per capita police expend. } & -0.003 & -0.003 & -0.003 & -0.003 & -0.003 & -0.003 & -0.003 & -0.003 \\
\hline & $(-1.274)$ & $(-1.309)$ & $(-1.345)$ & $(-1.222)$ & $(-1.160)$ & $(-1.278)$ & $(-1.278)$ & $(-1.289)$ \\
\hline \multirow[t]{2}{*}{ Lagged incarceration rate } & 0.0003 & 0.00031 & 0.00036 & 0.00027 & 0.00035 & 0.00031 & 0.00027 & 0.0002 \\
\hline & $(0.438)$ & $(0.454)$ & $(0.537)$ & $(0.385)$ & $(0.513)$ & $(0.455)$ & $(0.388)$ & $(0.283)$ \\
\hline \multirow[t]{2}{*}{ Percent with bachelor's degree } & -0.019 & -0.020 & -0.019 & -0.020 & -0.024 & -0.020 & -0.017 & -0.016 \\
\hline & $(-1.407)$ & $(-1.425)$ & $(-1.404)$ & $(-1.499)$ & $(-1.850)$ & $(-1.419)$ & $(-1.327)$ & $(-1.209)$ \\
\hline \multirow[t]{2}{*}{ Percent rural } & -0.183 & -0.177 & -0.176 & -0.180 & -0.203 & -0.186 & -0.186 & -0.190 \\
\hline & $(-2.442)$ & $(-2.342)$ & $(-2.307)$ & $(-2.403)$ & $(-2.744)$ & $(-2.438)$ & $(-2.491)$ & $(-2.625)$ \\
\hline
\end{tabular}

Notes: $N=542,353$. Coefficients from linear probability models with individual fixed effects shown.. Coefficients are multiplied by 100 for ease of interpretation. T-statistics in parentheses based on MSA-level clustered standard errors. Models also include indicator variables for the survey year. 
Table 5: NCVS Regressions for Alcohol or Drug Involved Assault Victimizations

\begin{tabular}{|c|c|c|c|c|c|c|c|c|}
\hline & $\begin{array}{c}\text { Model } \\
1\end{array}$ & $\begin{array}{c}\text { Model } \\
2\end{array}$ & $\begin{array}{c}\text { Model } \\
3\end{array}$ & $\begin{array}{c}\text { Model } \\
4\end{array}$ & $\begin{array}{c}\text { Model } \\
5\end{array}$ & $\begin{array}{c}\text { Model } \\
6\end{array}$ & $\begin{array}{c}\text { Model } \\
7\end{array}$ & $\begin{array}{c}\text { Model } \\
8\end{array}$ \\
\hline Real beer price & $\begin{array}{l}-0.0616 \\
-1.709)\end{array}$ & $\begin{array}{l}-0.0605 \\
-1.673)\end{array}$ & $\begin{array}{l}-0.0620 \\
(-1.700)\end{array}$ & $\begin{array}{l}-0.0637 \\
(-1.748)\end{array}$ & $\begin{array}{l}-0.0578 \\
(-1.577)\end{array}$ & $\begin{array}{c}-0.0616 \\
(-1.709)\end{array}$ & $\begin{array}{l}-0.0617 \\
(-1.705)\end{array}$ & $\begin{array}{l}-0.0617 \\
(-1.695)\end{array}$ \\
\hline Liquor outlets & $\begin{array}{l}0.0720 \\
(1.353)\end{array}$ & $\begin{array}{l}0.0712 \\
(1.344)\end{array}$ & $\begin{array}{l}0.0723 \\
(1.351)\end{array}$ & $\begin{array}{l}0.0712 \\
(1.339)\end{array}$ & $\begin{array}{l}0.0699 \\
(1.341)\end{array}$ & $\begin{array}{l}0.0719 \\
(1.346)\end{array}$ & $\begin{array}{l}0.0696 \\
(1.310)\end{array}$ & $\begin{array}{l}0.0841 \\
(1.433)\end{array}$ \\
\hline Keg info required & & $\begin{array}{l}-0.0487 \\
(-1.418)\end{array}$ & & & & & & \\
\hline Keg deposit & & & $\begin{array}{l}0.0003 \\
(0.645)\end{array}$ & & & & & \\
\hline ВАС08 & & & & $\begin{array}{l}0.0264 \\
(0.774)\end{array}$ & & & & \\
\hline Drivers license loss age 18 or 19 & & & & $\begin{array}{l}-0.0144 \\
(-0.091)\end{array}$ & & & & \\
\hline Drivers license loss age 21 & & & & $\begin{array}{l}-0.0181 \\
(-0.128)\end{array}$ & & & & \\
\hline Mandatory training & & & & & $\begin{array}{l}0.1506 \\
(2.080)\end{array}$ & & & \\
\hline Incentives for voluntary training & & & & & $\begin{array}{l}-0.1091 \\
(-2.772)\end{array}$ & & & \\
\hline Fake ID support & & & & & $\begin{array}{l}-0.0228 \\
(-0.401)\end{array}$ & & & \\
\hline Sunday ban & & & & & & $\begin{array}{l}0.0020 \\
(0.033)\end{array}$ & & \\
\hline Count of exceptions & & & & & & & $\begin{array}{l}-0.0801 \\
(-1.223)\end{array}$ & \\
\hline Open container federal standard & & & & & & & & $\begin{array}{l}-0.0512 \\
(-1.287)\end{array}$ \\
\hline
\end{tabular}

Notes: $\mathrm{N}=538,440$. Coefficients from linear probability models with individual fixed effects shown. Coefficients are multiplied by 100 for ease of interpretation. T-statistics in parentheses based on MSA-level clustered standard errors. Models also include indicator variables for the survey year and all individual and state characteristics listed in Table 4. 
Table 6: NCVS Regressions Including Tetrachoric Principal Component Analysis Factors

\begin{tabular}{|lcccc|}
\hline & \multicolumn{2}{c}{ All Assaults } & \multicolumn{2}{c|}{ Alcohol-Involved } \\
Assaults
\end{tabular}

Notes: $\mathrm{N}=542,353$ in the all assaults models and 538,440 in the alcohol or drug involved assaults models. Coefficients from linear probability models with individual fixed effects shown. Coefficients are multiplied by 100 for ease of interpretation. T-statistics in parentheses based on MSA-level clustered standard errors. Models also include indicator variables for the survey year and all individual and state characteristics listed in Table 4. 
Table 7: NCVS Regressions for Assault Victimizations Ages 18-29

\begin{tabular}{|c|c|c|c|c|}
\hline & \multicolumn{2}{|c|}{ All Assaults } & \multicolumn{2}{|c|}{$\begin{array}{c}\text { Alcohol or Drug Involved } \\
\text { Assaults }\end{array}$} \\
\hline & Model 1 & Model 2 & Model 1 & Model 2 \\
\hline \multirow[t]{2}{*}{ Real beer price } & -0.3941 & -0.3874 & -0.2306 & -0.2140 \\
\hline & $(-1.518)$ & $(-1.465)$ & $(-1.643)$ & $(-1.450)$ \\
\hline \multirow[t]{2}{*}{ Liquor outlets } & 0.2861 & 0.3766 & 0.4044 & 0.4717 \\
\hline & (1.063) & (1.249) & (2.376) & (2.495) \\
\hline \multirow[t]{2}{*}{ BAC .08 } & 0.1595 & & 0.2407 & \\
\hline & $(0.718)$ & & (1.156) & \\
\hline \multirow[t]{2}{*}{ Drivers license loss age 18 or 19} & -0.6874 & & -0.5846 & \\
\hline & $(-1.064)$ & & $(-1.639)$ & \\
\hline \multirow{2}{*}{ Drivers license loss age 21} & -0.7303 & & -0.6334 & \\
\hline & $(-2.066)$ & & $(-1.996)$ & \\
\hline \multirow[t]{2}{*}{ Restrictions factor 1} & & -0.1940 & & -0.0696 \\
\hline & & $(-1.219)$ & & $(-0.497)$ \\
\hline \multirow[t]{2}{*}{ Restrictions factor 2} & & 0.0558 & & -0.0001 \\
\hline & & $(0.279)$ & & $(-0.001)$ \\
\hline \multirow[t]{2}{*}{ Restrictions factor 3} & & 0.0601 & & -0.0747 \\
\hline & & $(0.325)$ & & $(-0.519)$ \\
\hline \multirow[t]{2}{*}{ Restrictions factor 4} & & -0.3101 & & -0.2007 \\
\hline & & $(-1.357)$ & & $(-1.177)$ \\
\hline \multirow[t]{2}{*}{ Exceptions factor 1} & & -0.3417 & & -0.7253 \\
\hline & & $(-0.762)$ & & $(-2.358)$ \\
\hline \multirow[t]{2}{*}{ Exceptions factor 2} & & -0.1676 & & 0.4243 \\
\hline & & $(-0.394)$ & & (1.494) \\
\hline
\end{tabular}

Notes: N=96,739 in the all assaults models and 95,508 in the alcohol or drug involved assaults models. Coefficients from linear probability models with individual fixed effects shown. Coefficients are multiplied by 100 for ease of interpretation. T-statistics in parentheses based on MSA-level clustered standard errors. Models also include indicator variables for the survey year and all individual and state characteristics listed in Table 4. 
Table 8: NCVS MSA Fixed Effects

\begin{tabular}{|c|c|c|c|c|c|c|c|c|}
\hline & \multicolumn{4}{|c|}{ MSA Fixed Effects, All Ages } & \multicolumn{4}{|c|}{ MSA Fixed Effects, 18-29 Year Olds } \\
\hline & \multicolumn{2}{|c|}{ All Assaults } & \multicolumn{2}{|c|}{$\begin{array}{l}\text { Alcohol or Drug } \\
\text { Involved Assaults }\end{array}$} & \multicolumn{2}{|c|}{ All Assaults } & \multicolumn{2}{|c|}{$\begin{array}{l}\text { Alcohol or Drug } \\
\text { Involved Assaults }\end{array}$} \\
\hline & Model 1 & Model 2 & Model 1 & Model 2 & $\begin{array}{c}\text { Model } \\
1\end{array}$ & $\begin{array}{c}\text { Model } \\
2\end{array}$ & $\begin{array}{c}\text { Model } \\
1\end{array}$ & $\begin{array}{c}\text { Model } \\
2\end{array}$ \\
\hline Real beer price & $\begin{array}{l}-0.0768 \\
(-1.609)\end{array}$ & $\begin{array}{l}-0.0696 \\
(-1.433)\end{array}$ & $\begin{array}{l}-0.0668 \\
(-2.911)\end{array}$ & $\begin{array}{l}-0.0560 \\
(-2.304)\end{array}$ & $\begin{array}{l}-0.2296 \\
(-1.259)\end{array}$ & $\begin{array}{l}-0.2169 \\
(-1.162)\end{array}$ & $\begin{array}{l}-0.1627 \\
(-1.724)\end{array}$ & $\begin{array}{l}-0.1085 \\
(-1.074)\end{array}$ \\
\hline Liquor outlets & $\begin{array}{l}0.0648 \\
(1.029)\end{array}$ & $\begin{array}{l}0.0779 \\
(1.156)\end{array}$ & $\begin{array}{l}0.0945 \\
(2.094)\end{array}$ & $\begin{array}{l}0.0849 \\
(1.726)\end{array}$ & $\begin{array}{l}0.1226 \\
(0.535)\end{array}$ & $\begin{array}{l}0.2073 \\
(0.854)\end{array}$ & $\begin{array}{l}0.3084 \\
(1.712)\end{array}$ & $\begin{array}{l}0.3371 \\
(1.622)\end{array}$ \\
\hline BAC .08 & $\begin{array}{l}0.0305 \\
(0.673)\end{array}$ & & $\begin{array}{l}0.0328 \\
(1.249)\end{array}$ & & $\begin{array}{l}0.0685 \\
(0.472)\end{array}$ & & $\begin{array}{l}0.2000 \\
(1.792)\end{array}$ & \\
\hline Drivers license loss age 18 or 19 & $\begin{array}{l}0.3257 \\
(2.336)\end{array}$ & & $\begin{array}{l}0.1020 \\
(0.975)\end{array}$ & & $\begin{array}{l}0.1429 \\
(0.396)\end{array}$ & & $\begin{array}{l}-0.0963 \\
(-0.454)\end{array}$ & \\
\hline Drivers license loss age 21 & $\begin{array}{l}0.2755 \\
(3.021)\end{array}$ & & $\begin{array}{l}0.0684 \\
(0.885)\end{array}$ & & $\begin{array}{l}0.4855 \\
(2.128)\end{array}$ & & $\begin{array}{l}-0.0528 \\
(-0.408)\end{array}$ & \\
\hline Restrictions factor 1 & & $\begin{array}{l}-0.0105 \\
(-0.224)\end{array}$ & & $\begin{array}{l}-0.0063 \\
(-0.262)\end{array}$ & & $\begin{array}{l}-0.3139 \\
(-2.467)\end{array}$ & & $\begin{array}{l}-0.0576 \\
(-0.693)\end{array}$ \\
\hline Restrictions factor 2 & & $\begin{array}{l}0.0647 \\
(1.301)\end{array}$ & & $\begin{array}{l}0.0079 \\
(0.270)\end{array}$ & & $\begin{array}{l}0.1349 \\
(1.110)\end{array}$ & & $\begin{array}{l}0.1000 \\
(1.548)\end{array}$ \\
\hline Restrictions factor 3 & & $\begin{array}{l}0.0331 \\
(0.943)\end{array}$ & & $\begin{array}{l}0.0069 \\
(0.458)\end{array}$ & & $\begin{array}{l}0.2463 \\
(2.134)\end{array}$ & & $\begin{array}{l}-0.0192 \\
(-0.307)\end{array}$ \\
\hline Restrictions factor 4 & & $\begin{array}{l}-0.0195 \\
(-0.399)\end{array}$ & & $\begin{array}{l}0.0140 \\
(0.673)\end{array}$ & & $\begin{array}{l}-0.1400 \\
(-1.025)\end{array}$ & & $\begin{array}{l}-0.0123 \\
(-0.123)\end{array}$ \\
\hline Exceptions factor 1 & & $\begin{array}{l}-0.0672 \\
(-0.994)\end{array}$ & & $\begin{array}{l}-0.0388 \\
(-1.333)\end{array}$ & & $\begin{array}{l}0.4907 \\
(3.444)\end{array}$ & & $\begin{array}{l}-0.2774 \\
(-1.836)\end{array}$ \\
\hline Exceptions factor 2 & & $\begin{array}{l}0.1190 \\
(2.376)\end{array}$ & & $\begin{array}{l}0.0442 \\
(1.588)\end{array}$ & & $\begin{array}{l}-0.1018 \\
(-0.570)\end{array}$ & & $\begin{array}{l}0.0913 \\
(0.922)\end{array}$ \\
\hline $\mathrm{N}$ & 542,353 & 542,353 & 538,440 & 538,440 & 96,739 & 96,739 & 95,508 & 95,508 \\
\hline
\end{tabular}

Notes: Coefficients from linear probability models shown, with MSA fixed effects. Coefficients are multiplied by 100 for ease of interpretation. T-statistics in parentheses based on MSA-level clustered standard errors shown. Models also include indicator variables for the survey year, all individual and state characteristics listed in Table 4, as well as controls for gender, race, and ethnicity. 